\title{
CONFIDENTIALITY
}

\section{AGREEMENTS AND THE PROTECTION OF TRADE SECRETS: DOES IT HAVE TO BE ALL OR NOTHING?}

\author{
Steve Kapnoullas* and Bruce Clarke*
}

[In Maggbury v Hafele, the High Court of Australia had to consider whether a perpetual restraint of trade clause in a confidentiality agreement was valid. The majority judgment, which refused to enforce the restraint, has been subject to criticism that it potentially puts confidentiality agreements at risk and hinders innovation. In spite of the criticism the authors of this article argue that the High Court decision was correct and that Maggbury provides valuable lessons for those drafting confidentiality agreements and seeking to protect trade secrets.]

\footnotetext{
* Senior Lecturer, Faculty of Business \& Enterprise, Swinburne University of Technology
} ${ }^{* *}$ Senior Lecturer, Faculty of Business \& Enterprise, Swinburne University of Technology 


\section{INTRODUCTION}

In Maggbury Pty. Ltd. v. Hafele Australia Pty. Ltd. ${ }^{1}$ (Maggbury) the High Court of Australia essentially dealt with two issues:

1. Whether public disclosure, by way of a patent application, destroys a trade secret;

2. The extent to which, if at all, the restraint of trade doctrine applies to confidentiality agreements.

A majority of the High Court held that a trade secret ceases to be protected once it has been made public and that the restraint of trade doctrine applies to confidentiality agreements.

The decision in Maggbury has been met with concern by a prominent firm of solicitors who contend that confidentiality agreements have been put at risk ${ }^{2}$. More recently, Brennan, ${ }^{3}$ in a critique of the court's decision, has 'concluded that it lends itself to an "all or nothing" approach to the enforceability of confidentiality agreements and that the application of the restraint of trade doctrine "may be legitimately questioned if an important public policy is the fostering of innovation." 4

In spite of these criticisms, this article will argue that the majority judgment in Maggbury, refusing to enforce a perpetual restraint, was correct. It will also be emphasised, however, that well drafted confidentiality agreements, which pay regard to the restraint of trade doctrine, will be more favourably viewed than 'carte blanche' prohibitions. ${ }^{5}$ It was such a prohibition that the High Court was asked to enforce in Maggbury.

\section{THE FACTS OF MAGgBURY}

Maggbury entered into two confidentiality agreements with Hafele, a German company, with respect to Maggbury's invention, which consisted of a space saving foldaway ironing board. The two agreements were with Hafele's German parent company and its Australian subsidiary, and were very similar in nature. The agreements were to be governed by Queensland law. It should be noted that unlike New South Wales, which has statutory provisions allowing restraint of trade

\footnotetext{
1 (2001) 210 CLR 181. (High Court of Australia, 2001).

${ }^{2}$ See: Ruling Puts Confidentiality Deals at Risk, The Australian Financial Review (Sydney), Jan. 7, 2002, and A. Stone \& K. Everett, Confidentiality Agreements - Has The High Court Put Them At Risk?, 15 (1) AUSTRALIAN I.P. BULLETIN. 1 (2002).

${ }^{3}$ David J. Brennan, Springboards and Ironing Boards: Confidential Information as a Restraint of Trade, 21 JOURNAL OF CONTRACT LAW 71, (2005).

${ }^{4}$ Id. at 72 .

${ }^{5}$ Warren. Pengilley, Confidentiality Agreements Cannot Operate in Respect of Information in the Public Domain, 18 (2) Australian N.Z.T.P. Bull. 18, 22 (2002).
} 
clauses to be read down on public policy grounds, ${ }^{6}$ other states of Australia, including Queensland, have no such equivalent statute.

There is no need to go into the precise detail as to the terms of the confidentiality agreements used in Maggbury. ${ }^{7}$ The most important terms were as follows.

Maggbury was defined as 'the Inventor'. The recitals were set out in clause 2. They stated:

2.1 The Inventor wishes to commercially exploit the Product.

2.2 The Inventor and Hafele [Australia] wish to hold discussions to consider mutually advantageous ways of commercially exploiting the Product (the 'Purpose').

2.3 In the course of these discussions the Inventor or his representatives may disclose information about the Product to Hafele [Australia].

2.4 The Inventor and Hafele [Australia] have entered into this Deed so as to set out the terms and conditions governing any disclosure by the Inventor about the Product.

2.5 Hafele [Australia] has agreed to enter into this Deed to acknowledge the right title and interest of the Inventor in the Product and to scrupulously observe a strict code of confidentiality in relation to the Product.

“Information” was defined in clause 3 as follows.

'Information' means each and every record of information whatsoever disclosed, shown or provided to Hafele [Australia] by the Inventor in relation to the Product and, without limiting the generality thereof, includes any writing, sketches, diagrams, models, film, video tape, plans, designs, manufactured prototypes, layouts, schedules or photographs.

The agreement went on to make provisions regarding the use of information:

5.1 Hafele [Australia] shall treat the Information as private and confidential.

5.2 Hafele [Australia] shall not use the Information, or any part thereof, for any purpose other than to fairly and properly assess proposals canvassed with the Inventor in relation to the Purpose.

5.3 Hafele [Australia] shall take all reasonable steps to ensure that the Information is made known only to [particular officers or employees of Hafele [Australia] identified as the 'Permitted Persons']

$\ldots$

\footnotetext{
${ }^{6}$ Restraints of Trade Act, 1976, (NSW).

${ }^{7}$ These are referred to in the majority judgment of Gleeson CJ, Gummow and Hayne JJ in Maggbury Pty. Ltd. v. Hafele Australia Pty. Ltd,. (2001) 210 CLR 181, 189-191 (High Court of Australia, 2001).
} 
5.6 Hafele [Australia] shall not at any time hereafter use the Information for any purpose whatsoever except with the Inventor's informed prior written consent. [Emphasis added].

Clause 11 was headed 'Duration' and stated:

It is a condition of this agreement that Hafele [Australia] will forever observe the obligations of confidence set out in this Agreement, unless released from such obligations in writing by the Inventor. [Emphasis added]. Without limiting the generality of this condition, Hafele [Australia] agrees to continue to observe its obligations as to confidentiality:

(a) upon the signing of this agreement;

(b) while the Purpose is being carried out;

(c) after the Information is returned; or

(d) after Hafele [Australia] becomes liable to return the Information.

In essence, the agreements provided that if no contractual arrangement was entered into between the parties to exploit Maggbury's invention then Hafele would not use the information supplied to it by Maggbury and would return all the information supplied.

Three points should be emphasised at this stage. First, the restraint imposed on Hafele was unlimited in duration. Secondly, the invention was subject to a patent application. Furthermore, at Hafele's urging, Maggbury exhibited the invention at trade fairs. Thirdly, the agreement did not contain any exception to the obligations of confidentiality should the information become part of the public domain.

After extensive correspondence and negotiations with Maggbury, Hafele decided not to enter into an agreement to exploit and commercialise the invention. Shortly afterwards Hafele commenced marketing foldaway ironing boards based on Maggbury's invention. As a consequence, Maggbury commenced proceedings seeking an injunction preventing Hafele marketing the products in breach of the confidentiality agreement.

The trial judge, Byrne J, awarded Maggbury \$25,000 damages and granted an injunction restraining Hafele from manufacturing or distributing the current Hafele wall-mounted ironing board. ${ }^{8}$ The injunction extended to any other wallmounted ironing board designed or manufactured using wholly or in part information derived directly or indirectly from the document or prototype supplied by Maggbury to Hafele. ${ }^{9}$ Hafele appealed to the Queensland Court of Appeal which

\footnotetext{
${ }^{8}$ Maggbury Pty. Ltd. v. Hafele Australia Pty. Ltd. and Hafele Gmbh. \& Co. (unreported) [1999] QSC 4 (Qld. Supreme Court, 1999).

9 The injunction is referred to in the majority judgment of the High Court in Maggbury Pty. Ltd. v. Hafele Australia Pty. Ltd., (2001) 210 CLR 181, 193-194.
} 
set aside the injunction and reduced the damages awarded to $\$ 5,000$. Maggbury then appealed to the High Court seeking restoration of the perpetual injunction.

The issues which the High Court had to deal with were essentially the same as those before the Court of Appeal, viz.

...[D]id the adequate protection of Maggbury's interests require that [Hafele] be prevented from using information covered by the agreements even after it had been disclosed to the world? And did it require such protection permanently? ${ }^{10}$

\section{III \\ Applying for Patent Protection: Does it Destroy CONFIDENTIALITY?}

The majority of the High Court, Gleeson CJ, Gummow and Hayne JJ, dismissed Maggbury's appeal. Maggbury, by applying for patent protection, had made its invention public. A secret, as a secret, had ceased to exist. The majority referred to the House of Lords decision in O. Mustad \& Son v. Allcock \& Co. Ltd. ${ }^{11}$ In that case an injunction, sought to prevent the disclosure of confidential information, was refused because the plaintiff had applied for a patent. The House of Lords held that a contractual restraint does not apply once the information has become public, and that an injunction should not issue restraining the defendants from disclosing what was common knowledge. ${ }^{12}$ In Maggbury the confidentiality agreements were explicit in intent and prevented the use of all information supplied by Maggbury, for any purpose and for all time. The agreements were not confined to confidential information.

It should be noted that the High Court did not find it necessary to decide whether the information had lost its confidentiality and become public as a result of Maggbury's application for a patent, or the exhibition of its invention at trade fairs. The simple fact was that the information had entered the public domain.

Kirby J was of the opinion that Hafele was bound by the obligation of confidentiality because the subject matter of Hafele's covenants was not information in a generic sense, but restricted information defined by the confidentiality agreements that Hafele promised to treat as confidential. Similarly, Callinan J was of the view that the information was not provided by Maggbury with a covenant that it had a confidential character. It was simply information that Hafele had promised not to use or disclose. Under such circumstances the patent disclosure did not destroy the obligation of confidentiality.

\footnotetext{
${ }^{10}$ Unreported [2000] QCA 172 para [13], (Qld. C.A. 2000).

${ }^{11}$ [1963] 3 AllER 416 (House of Lords, 1963). See also Franchi v. Franchi [1967] RPC 149 (UK. Chancery, 1963).

${ }^{12}$ Cf. Attorney General v. Blake [2001] AC 268 (House of Lords, 2001).
} 
With respect to their Honours Kirby and Callinan JJ, we disagree with their conclusions. The essence of the equitable doctrine of confidentiality is that the information must have the necessary quality of confidence about it. ${ }^{13}$ Furthermore, the views expressed by Kirby and Callinan JJ appear to be inconsistent with those of the House of Lords in O. Mustad \& Son v. S. Allcock \& Co. Ltd., ${ }^{14}$ that the obligation to publicly disclose, required as part of the process of applying for a patent, destroys confidentiality.

Related to this, we refer to the judgment of the Court of Appeal in Maggbury: ${ }^{15}$

[I]t appears to us impossible to conclude that requiring [Hafele], where a design feature can be drawn from a public source or from Maggbury's information, to use only the former, is no more than is necessary to protect Maggbury's interest in that information. Where the information is public, having been made so by Maggbury, it would not become less so if the terms of the agreements are followed by [Hafele]; the only outcome of their compliance which would be potentially useful to Maggbury would be a complication, and therefore a hindrance, in the conduct of [Hafele's] business - not the preservation of secrets.

\section{Does the Restraint of Trade Doctrine Apply to CONFIDENTIALITY AGREEMENTS?}

\section{A The Majority Judgment}

The majority decision was predicated upon the application of the restraint of trade doctrine to the confidentiality agreements entered into between Maggbury and Hafele. Consistent with its recent decision in Peters (WA) Ltd. v. Petersville Ltd., ${ }^{16}$ the court held that the agreements were subject to the doctrine. The majority emphasised that the fact that the restraint could be said to have been freely bargained for by the parties provided no sufficient basis for concluding that the restraint of trade doctrine did not apply. "All contractual restraints could be said to be of that character."17

The onus was on the plaintiff to show that the restraints were reasonable. The fact that there was no temporal limit made that task difficult, and the terms of the

\footnotetext{
${ }^{13}$ See Coco v. A. N. Clark (Engineering) Ltd., [1969] RPC [No 2] 41 (UK. Chancery, 1969) and the judgment of Gummow J in Smith Kline \& French Laboratories (Australia) Ltd. v. Secretary Department of Community Services and Health ,(1990) 95 ALR 87 (Federal Court of Australia, 1990).

${ }^{14}$ O. Mustad \& Son v. S. Allcock \& Co. Ltd. [1963] 3 All ER 416 (House of Lords, 1963).

${ }^{15}$ Unreported [2000] QCA 172 para [15], (Qld. C.A. 2000) .

${ }^{16}$ Peters (WA) Ltd. v. Petersville Ltd. (2001) 205 CLR 126 (High Court of Australia, 2001); discussed by Warren Pengilley, High Court dissents from the House of Lords view in relation to the restraint of trade doctrine 17(5) AustraLian N.Z.T. P. L.BuLL. 4 (2001).

${ }^{17}$ Maggbury Pty. Ltd. v. Hafele Australia Pty. Ltd., (2001) 210 CLR 181, 203.
} 
restraint seemingly went beyond reasonable protection of Maggbury's interests. The majority concluded that as no attempt had been made to justify the restraints as reasonable in the interests of the public and the parties at trial, they were invalid.

It is appropriate to make two observations at this stage. First, the court did not feel it necessary to consider whether the restraints could be severed or read down. ${ }^{18}$ Secondly, the court determined that it did not need to consider the applicability of the head start or springboard doctrine in any detail, because the injunction sought and granted at trial was a permanent one.

\section{B The Minority Judgments}

\section{$1 \quad$ Kirby J}

His Honour, Justice Kirby, held that the restraint of trade doctrine did not apply to the confidentiality agreements. Hafele freely negotiated the agreements and rather than being in a vulnerable position was in a much stronger economic position than Maggbury.

Both parties to the confidentiality agreements were advised by lawyers and other experts. Hafele executed the agreement with its eyes wide open. It made highly specific promises of a particular character. By the execution of the confidentiality agreements, it agreed to be bound to those promises. $^{19}$

His Honour held that Hafele was not restrained in its trade because the definition of the prohibited acts was quite narrow. ${ }^{20}$ Hafele could continue in its trade, provided it did not make use of information disclosed to it by Maggbury. ${ }^{21}$ Hafele could proceed, independently of 'the Information' acquired from Maggbury, to invent such ironing boards and to market them without restriction, so long as it used its own internal ideas or information acquired without legal inhibition from third parties, or from data in the public domain, unaffected by the restriction to which it had agreed.

His Honour also held that there were policy reasons in support of upholding such restraints, in that it would encourage invention. Kirby J referred to the US District

\footnotetext{
${ }^{18}$ Maggbury Pty. Ltd. v. Hafele Australia Pty. Ltd., (2001) 210 CLR 181, 204 where the majority said, "If read down, this would be on the footing that the restraints did not operate where, at the time of the breach or threatened breach in question, the subject matter has lost its confidential quality and had entered the public domain as a result of steps taken by or to be attributed to Maggbury.”

${ }^{19}$ Maggbury Pty. Ltd. v. Hafele Australia Pty. Ltd., (2001) 210 CLR 181, 205. It should be noted that this is consistent with his Honour's view in Wright v Gasweld Pty Ltd, (1991) 22 NSWLR 317, 337 (NSW C.A., 1991) that the clear policy behind the Restraints of Trade Act, 1976 (NSW) is that parties should be held to their agreements, which is a policy that has general application at law.

${ }^{20}$ Maggbury Pty. Ltd. v. Hafele Australia Pty. Ltd. (2001) 210 CLR 181, 207.

${ }^{21}$ Maggbury Pty. Ltd. v. Hafele Australia Pty. Ltd. (2001) 210 CLR 181, 207.
} 
Court of Florida decision in Biodynamic Technologies Inc. v. Chattanooga Corp., ${ }^{22}$ where the court said

The principle that because a secret is of such a nature that it can be discovered by lawful means does not deprive its owner of a right to protection from those who obtain it unlawfully is not only generally accepted, it is also sagacious. Any other policy would have a halting effect on commercial transactions. The owners of new and unpatented products would hesitate before transmitting the information and making the disclosures essential to bring about meaningful negotiations. Such protections of confidential disclosures serve to promote the negotiation of profitable business relationships. ${ }^{23}$

Kirby $\mathrm{J}$ then went on to hold that the terms of the injunctive relief were proper given that the breaches of the confidentiality agreements were deliberate and flagrant. The terms of the injunction were not impermissibly wide because, in essence, it held the defendant to its promise. $^{24}$

Further analysis of Kirby J's judgment will be attempted below. However, it is appropriate to mention at this point that his Honour was part of the majority in Peters (WA) Ltd. v. Petersville Ltd., ${ }^{25}$ previously referred to, where the High Court appeared to widen the applicability of the restraint of the trade doctrine. Furthermore, although his Honour made a passing reference to a temporary "springboard injunction" in his judgment, ${ }^{26}$ there is no detailed discussion as to why a permanent injunction was a preferable remedy, rather than an injunction limited in terms of time. In this respect, it will be recalled that the majority view was that as no attempt was made at trial to argue for a more limited injunction, it was not an issue that required further consideration.

\section{Callinan J}

Callinan $\mathrm{J}$ emphasised policy reasons for holding Hafele to its promises. His Honour referred to the judgment of Heerey $\mathrm{J}$ in Australian Capital Territory $v$. Munday ${ }^{27}$ where Heerey J said:

When one party does seek to invoke the doctrine it will usually not be for any lofty motives of public interest. It has not escaped the notice of the courts that sometimes parties of relatively equal bargaining strength freely

\footnotetext{
22 (1986) 644 F Supp 607 (US. District Court, 1986).

${ }^{23}$ (1986) 644 F Supp 607 at 611 (US. District Court, 1986).

${ }^{24}$ Maggbury Pty. Ltd. v. Hafele Australia Pty. Ltd., (2001) 210 CLR 181, 209 (High Court of Australia, 2001) where his Honour posed the question "Why should Hafele now be heard to resist the remedy to which it expressly agreed in respect of the precise circumstances that have occurred?”.

${ }^{25}$ (2001) 205 CLR 126 (High Court of Australia, 2001).

${ }^{26}$ Maggbury Pty. Ltd. v. Hafele Australia Pty. Ltd., (2001) 210 CLR 181, 210

${ }^{27}$ (2000) 99 FLR 72 (Federal Court of Australia, 2000).
} 
enter into a contract but later one finds a more attractive proposition elsewhere and seeks to be released. ${ }^{28}$

Callinan J continued, stating that if unconstrained by authority, a just result would be to hold Hafele to the contracts, given that it had entered into them voluntarily with the benefit of legal advice. However, his Honour concluded that he was bound to apply the restraint of trade doctrine according to settled principles, because of the High Court's decision in Peters (WA) Ltd. v. Petersville Ltd. ${ }^{29}$ referred to above.

Nevertheless, Callinan J ultimately held that the restraints were reasonable, for a number of reasons, ${ }^{30}$ many of which were similar to those expressed by Kirby J. This was despite the fact that the restraint was unlimited in terms of time and place. As his Honour observed, from time to time the courts have granted a permanent injunction in such circumstances. ${ }^{31}$ The reasons given by his Honour for granting the injunction were many. To begin with, it was observed that the parties were engaged in a commercial negotiation in which Hafele was on an equal, if not superior, footing to Maggbury. Furthermore, Hafele had the benefit of legal advice. In particular:

- Hafele was left with its pre-existing freedom to trade.

- Any economic harm to the public would be trivial or non-existent.

- The restraints did not inhibit competition - rather they were a means of encouraging the inventor to disclose information essential to comercialise their product.

- The absence of a geographical restraint was not important, as the market was international.

Accordingly the restraint went no further than was necessary in the interests of the parties, and was not contrary to public interest. His Honour then dealt with the issue of public disclosure, which the Court of Appeal considered significant in terms of whether an injunction was appropriate. Callinan $\mathrm{J}$ concluded ${ }^{32}$ that Hafele

...undertook, by covenant, irrespective of whether a patent might emerge or not, not to use or reveal what [Maggbury] made available to them. Nothing, therefore, in my opinion, turns upon the public exhibition, in which [Maggbury] participated, of the subject matter of the agreement between the parties. ${ }^{33}$

\footnotetext{
${ }^{28}$ Australian Capital Territory v. Munday, (2000) 99 FLR 72, 92 (Full Federal Court of Australia, 2000). ${ }^{29}$ (2001) 205 CLR 126.

${ }^{30}$ Maggbury Pty. Ltd. v. Hafele Australia Pty. Ltd., (2001) 210 CLR 181, 217-218.

${ }^{31}$ Maggbury Pty. Ltd. v. Hafele Australia Pty. Ltd., (2001) 210 CLR 181, 217.

${ }^{32}$ Referring to J. D HEYDON, THE RESTRAINT OF TRADE DoCTRINE 131-132 (2d ed. 1999) for a discussion of cases where life-long restraints were held to be valid; and A.R. Carnegie, Terminability of Contracts of Unspecified Duration, 85 LAW Q. REV. 392 (1969).

${ }^{33}$ Maggbury Pty. Ltd. v. Hafele Australia Pty. Ltd. (2001) 210 CLR 181, 218.
} 
Like Kirby J, his Honour concluded that the terms of the injunction were not too wide and would have the legitimate effect of restraining the defendants from committing a clear breach of the confidentiality agreements.

\section{The Springboard or Head Start Doctrine}

In a recent article by Brennan, ${ }^{34}$ referred to in the introduction to this article, the author argues that a more rational solution for the High Court to have adopted was to apply the springboard doctrine and to have awarded a temporary injunction to Maggbury based on the head start obtained by Hafele's use of the confidential information supplied to it.

The essence of the doctrine is that the user of confidential information may obtain a distinct head start by virtue of the misuse of that information, for example, by progressing to a point of having a product ready for the market more quickly than otherwise would have been the case. ${ }^{35}$ The appropriate remedy in such cases will often be a temporary injunction imposing a handicap on the person misusing the information. However, if the confidential information has been published to the world a more appropriate remedy may be damages. ${ }^{36}$

In this context the majority judgment of the High Court stated:

A construction of the restraints in the two agreements which gave them a limited temporal operation after public disclosure and after failure of the negotiations might be supported as the contractual imposition upon the Hafele companies of a 'head start' handicap. ${ }^{37}$

This would reflect the advantage to those companies, over the position of competitors who had not dealt with Maggbury, of having had access to the information over a period preceding its public disclosure. Kirby J, in his judgment, also referred to the head start obtained by Hafele. ${ }^{38}$ But as the majority judgment makes clear, it was unnecessary for the High Court to consider this question because Maggbury sought the restoration of the perpetual injunction, based on the assumption that the confidential quality of the information in question still persisted.

\footnotetext{
${ }^{34}$ Brennan, supra note 3.

${ }^{35}$ See United States Surgical Corp. v. Hospital Products International Pty. Ltd., [1983] 2 NSWLR 157, 228-33 (NSW. A.C., 1983) for a discussion of the authorities on this point; see also R. DEAN, THE LAW of TRAdE SECRETS 305-307 (1990) and R.P. MEAgheR, JD HEYdON \& MJ LEEMING, EQUiTY DOCTRINES AND REMEDIES 1126 ( $4^{\text {th }}$ ed. 2002).

${ }^{36}$ See Speed Seal Products Ltd. v. Paddington, [1986] All ER 91 (Eng. C.A. 1986) and Aquaculture Corp. v. New Zealand Green Mussel Co. Ltd., (1990) 19 IPR 527 (NZ. C.A. 1990).

${ }^{37}$ Maggbury Pty. Ltd. v. Hafele Australia Pty. Ltd., (2001) 210 CLR 181, 201.

${ }^{38}$ Maggbury Pty. Ltd. v. Hafele Australia Pty. Ltd. (2001) 210 CLR 181, 206, where his Honour said, "Hafele Germany received the final production drawings of the new prototype 'in accordance with our confidentiality agreement' [with Maggbury]. At the very least this gave Hafele a head start in development of its own products based upon those materials.”
} 
The imposition of a temporary injunction would to some extent have overcome the problem of distinguishing between the use by Hafele of information that was confidential and information that had passed into the public domain.

\section{LesSONS From Maggbury}

\section{A There is a danger in trying to commercialise an inven- tion without obtaining patent protection first}

The majority judgment makes it clear that there is a danger in applying for patent protection whilst at the same time attempting to rely on a confidentiality agreement. Stone and Everett ${ }^{39}$ conclude " $[t]$ he case reinforces the need for every inventor who is considering applying for a patent to weigh up the conflicting benefits of relying on patents or confidential information to protect their inventions." Thus it has been argued that Maggbury makes it difficult for inventors wishing to gauge consumer demand for their product. ${ }^{40}$ There is some validity to these arguments. However, whilst Maggbury does pose some problems for inventors, it is the writers' opinion that the High Court was applying settled principles that the law of confidentiality is meant to apply to trade secrets, not to information publicly available. It should be noted that Hafele obviously took the chance that Maggbury's application for a patent would not be successful, otherwise they would have been liable to pay damages as from the date of the patent application. ${ }^{41}$

The effect of the court's decision has been somewhat mitigated by the passing of the Patents Amendment (Innovation Patents) Act, 2000, (Cth), which has introduced an alternative protection option for inventions, the innovation patent. The potential advantage of utilising an innovation patent as a vehicle of protection, in circumstances like those faced by Maggbury, should not be overlooked nowadays. The Act has introduced a simple process of patenting and extends patentability to those incremental and lower level inventions that would not be sufficiently inventive to qualify for standard patent protection. All that is required is an innovative step. A significant advantage of this new patent is the presumption of validity. Following a quick 'formalities' check, an innovation patent is granted immediately to an applicant, and then remains in force for a maximum of 8 years. ${ }^{42}$

\footnotetext{
${ }^{39}$ Stone \& Everett, supra note 2.

${ }^{40}$ See Pengilley, supra note 5, at 22.

${ }^{41}$ Id. See also R. Reynolds \& N. P. Stoianoff, Intellectual Property: TeXt AND EsSEntial CASES, 528 (2003).

${ }^{42}$ This is not to suggest that the innovation patent does not have a downside. It must be certified to be enforceable. This requires a request for an examination and payment of appropriate fees.
} 


\section{B The Restraint of Trade Doctrine Applies to Confidentiality Agreements}

As discussed earlier, Kirby $\mathrm{J}$ was of the opinion that the restraint of trade doctrine was inapplicable to the confidentiality agreements entered into between the parties. As previously indicated this view appears to be at odds with the High Court's decision in Peters (WA) Ltd. v. Petersville Ltd. ${ }^{43}$ Although it was true that Hafele could still carry on its trade, the object of the confidentiality agreements undoubtedly was to impose a restraint upon the use by Hafele of 'confidential' information supplied to it by Maggbury. Given such an imposition, with respect to Kirby J, the critical question for the court to consider in Maggbury was not whether the doctrine was applicable, but whether the restraint was reasonable.

Both their Honours Kirby and Callinan JJ considered that there were strong public policy arguments supporting the restraints, particularly because Hafele was in a stronger economic position than Maggbury and that both parties voluntarily entered into the agreements with the benefit of legal advice. We would agree with their Honours' observations, but with respect, we believe that ultimately the question that the court had to answer was whether a restraint, not limited in time and place, went beyond what was reasonably required to protect Maggbury’s interests.

It is appropriate to quote from the judgment of the Court of Appeal: ${ }^{44}$

The difficulty in the path of Maggbury is that it has to show (the onus being upon it) the propriety of the restraint, from the point of view of protection of its own interests. It has the advantage that the law will allow the parties considerable freedom, where they are bargaining on an equal footing, to judge what is reasonable in their own interests: [Amoco Australia Pty. Ltd. v. Rocca Bros. Motor Engineering Co., (1973) 133 CLR 288] at 316, 317.

As the majority judgment of the High Court makes clear, no attempt was made by Maggbury at trial to justify the restraint. It is not sufficient to simply argue that the parties to the contract had freely bargained the restraint. Such a fact is not a sufficient reason for concluding that the restraint of trade doctrine should not apply. $^{45}$

\footnotetext{
43 (2001) 205 CLR 126, (High Court of Australia, 2001).

${ }^{44}$ Unreported [2000] QCA 172 para [15], (Qld. C.A. 2000).

${ }^{45}$ Maggbury Pty. Ltd. v. Hafele Australia Pty. Ltd. (2001) 210 CLR 181, 203.
} 


\section{Restraints Must Be Reasonable}

Given the applicability of the restraint of trade doctrine in such cases, it is appropriate to quote Dr. W. Pengilley, ${ }^{46}$ who makes the following observation with regard to Maggbury:

The case, once again, shows the need for drafting conservatism. Limitations as to time, geography and type of conduct to be restrained are always more favourably viewed by the courts than carte blanche prohibitions. Validity of restraints for short periods (for example, a period which would have prevented Hafele from getting a head start on Maggbury in exploiting the product involved) are more likely to be blessed than eternal restraints. The majority judgment clearly recoils at the prospect of a restraint on using the information 'for any purpose' 'at any time'. ${ }^{47}$

\section{The Springboard Doctrine may be used to obtain a tem- porary injunction}

As is implied from the quote of Pengilley above, in cases such as Maggbury, it is possible to argue for the imposition of a temporary injunction using the springboard doctrine. Although it appears that this was argued before the trial judge, the problem for the High Court was that it was not asked to consider this issue, as Maggbury sought the restoration of the perpetual injunction. The majority judgment should be analysed in the light of the issues before the court, which were limited in nature. It is for this reason that we believe that much of the criticism of the court's decision is unwarranted. As one of the critics of the case concedes:

It may be that it is possible to exaggerate the extent to which in Maggbury the desirable outcomes of providing incentives for facilitating competitive trade are in conflict...It seems that Hafele should not be restrained 'forever', but nor should it be able to opportunistically expropriate the value of [Maggbury's] information without regard to the contractual relationship of confidence...[I]t may well be that injunctions limited to reasonable periods, or restitutionary monetary sums for springboarding uses over such periods will provide more compelling remedial alternatives to the 'all or nothing' response of which Maggbury is an example. ${ }^{48}$

\footnotetext{
${ }^{46}$ Pengilley, supra note 5, at 22.

${ }^{47}$ See also J. McKeough \& A. Stewart, Intellectual Property in Australia, para.4.6 (2d ed. 1997) who conclude that "A 'global' claim covering a wide range of information will be rejected, no matter how clear it is that some of the information is secret.”: referring to O’Brien v Komesaroff (1982) 150 CLR 310, 328 (High Court of Australia, 1982).

${ }^{48}$ Brennan, supra note 3, at 95.
} 


\section{CONCLUSION}

It is contended that the view expressed in the introduction to this article, that the High Court has put confidentiality agreements at risk, overdramatises the effect of Maggbury. ${ }^{49}$

In essence the High Court has simply confirmed two things:

1) That information only remains confidential if it has not passed into the public domain; and

2) That the restraint of trade doctrine applies to confidentiality agreements.

In respect to the first, Maggbury confirms the danger of seeking to rely on confidential information at the same time as pursuing patent protection. As to the second point, the suggestion that the restraint of trade doctrine should not apply to confidentiality agreements, as put forward by Kirby J in Maggbury, seems to lose sight of the fact that the right to protect confidential information is by its very nature is an ephemeral right. ${ }^{50}$ It is always vulnerable to independent development or discovery by another; only the patent protects against such risks, and even then only for a defined period. It should not be forgotten that a patent is a limited monopoly right - it has a restricted life before it too becomes public property.

To allow untrammelled freedom of contract to override these considerations is against the public interest. It is the restraint of trade doctrine that performs the role of ensuring that there is a balance between protecting secrets and at the same time ensuring that such protection does not exceed reasonable bounds. Richardson observes that the doctrine, properly tailored, has one particularly useful purpose:

If all it does is ensure the natural term of trade secret protection is the life of the trade secret, the length of time before it fully reaches the public domain, it avoids the illogical and anomalous situation of a contract continuing to operate when its basis has been destroyed. ${ }^{51}$

\footnotetext{
${ }^{49}$ See Stone \& Everett, supra note 2. Cf. M. Richardson, Of Shrink-Wraps, 'Click-Wraps' and Reverse Engineering: Re-thinking Trade Secret Protection 25 UNIVERSITY N.S.W.L.J. 748, 755 (2002) who says, 'Although the facts of the case were extreme [the information had been published by the plaintiff in a patent application so was no longer secret] the generalised language of the High Court's judgment might be taken to support a judicial lack of enthusiasm for protection of trade secrets-at least where extending beyond the equitable scope.'

${ }^{50} \mathrm{Id}$. at 763 .

${ }^{51}$ Id. at 765 .
} 
The Queensland Court of Appeal, in Maggbury, made it clear that the courts allow parties considerable latitude in drafting confidentiality agreements, particularly where they are on equal bargaining footing. However, the High Court's decision in Maggbury also illustrates the reluctance of the courts to give effect to ambit claims.

\footnotetext{
52 See McKeough \& Stewart, supra note 47 and Reynolds \& StoianofF, supra note 41, who conclude that a consequence of Gummow J's formulation of the requirements for an action for breach of confidence, in Smith Kline \& French Laboratories (Australia) Ltd. v. Secretary, Department of Community Services and Health, (1990) 95 ALR 87 (Federal Court of Australia, 1990), has been to encourage careful drafting of confidentiality agreements so as not to fall foul of the requirements of equity.
} 